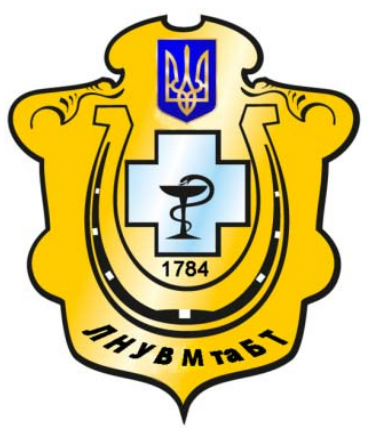

Науковий вісник Львівського національного університету ветеринарної медицини та біотехнологій імені С.3. Гжицького

Scientific Messenger of Lviv National University of Veterinary Medicine and Biotechnologies named after S.Z. Gzhytskyj

doi:10.15421/nvlvet6904

ISSN 2413-5550 print

ISSN 2518-1327 online

http://nvlvet.com.ua/

УДК 628.1:338

\title{
Рекреаційні зони Закарпаття: стан і перспективи розвитку
}

\author{
К.М. Гірняк, М.В. Багрій \\ girnjak@mail.ru
}

\begin{abstract}
Львівський національний університет ветеринарної медицини та біотехнологій імені С.З. Гжицького, вул. Пекарська, 50, м. Львів, 79010, Украӥна
\end{abstract}

У статті розглянуто перспективи стану та розвитку рекреаційних зон Закарпаття. Визначено, щчо саме Закарпаття має великі рекреаційні ресурси, до яких належать географічні об'єкти, щзо використовуються і можуть бути використані для відпочинку, туризму, лікування, оздоровлення населення, а також суттєво вплинути на розвиток економіки регіону.

Проведено функиіональне зонування рекреаційних територій, яке необхідне для внутрішньорегіональної рекреаційної політики, регіонального управління та регулювання визначення рекреаційної спеціалізації, яка дасть імпульс до вирівнювання сочіально-економічної ситуації в усіх адміністративних районах області.

Дослідженням визначено особливості економічних туристично-рекреаціійних ресурсів у системі новітніх рекреацій 3 карпатської області, що використовують сучасні показники розвитку суспільства, зокрема конкурентоспроможності та економічної глобалізації. Подано сучасні і оригінальні поняття, зокрема «рекреаційна зона» сукупність рекреачійних регіонів, які формуються на основі територіальної близькості, наявності транспортних і функціональних зв'язків $i$ загального рекреаційного ресурсу. Проведено рекреаційне зонування для отримання інформації про придатність їх територій для туристично-рекреаційного використання.

В статті авторами здійснено рекреаційне зонування де виділено десять рекреаційних зон, в яких визначено критеріі придатності території для рекреаційно-оздоровчого використання. Доведено, щъо Закарпаття мальовничий куточок, щзо займає особливе місие у плані розвитку рекреаційного комплексу Украӥни, який є унікальний за своїми ресурсами $і$ за свойм геоекономічним положенням у світі, щзо робить область привабливою для оздоровлення та відпочинку людей і створює пріоритетний розвиток рекреаціï у Закарпатті.

Ключові слова: туризм, рекреаційна зона, рекреачійні ресурси, рекреаційне зонування, область, галузь, інформація, аналіз, напрям, економіка, формування.

\section{Рекреационные зоны Закарпатье: состояние и перспективы развития}

\author{
К.М. Гирняк, М.В. Багрий \\ girnjak@mail.ru
}

\begin{abstract}
Львовский наџиональный университет ветеринарной медицины и биотехнологий имени С.3. Гжицького, ул. Пекарская, 50, г. Львов, 79010, Украина,
\end{abstract}

В статье рассмотрены перспективы состояния и развития рекреационных зон Закарпатья. Определено, что именно Закарпатье имеет большие рекреационные ресурсы, к которым относятся географические объекты, используются и могут быть использованы для отдыха, туризма, лечения, оздоровления населения, а также существенно повлиять на развитие экономики региона.

Проведено функциональное зонирование рекреационных территорий, которое необходимо для внутрирегиональной рекреационной политики, регионального управления и регулирования определения рекреационной специализаџии, которая даст импульс к выравниванию сочиально-экономической ситуачии во всех административных районах области.

Исследованием определены особенности экономических туристично-рекреациийных ресурсов в системе новейших рекреаций Закарпатской области, используют современные показатели развития общества, в частности конкурентоспособности и экономической глобализации. Подано современные и оригинальные понятия, в частности «рекреационная зона»-

\section{Citation:}

Hirnyak, K, Bagriy, M. (2016). Recreational areas of Zakarpattia: the state and prospects of development. Scientific Messenger LNUVMBT named after S.Z. Gzhytskyj, 18, 2(69), 17-21. 
совокупность рекреационных регионов, которые формируются на основе территориальной близости, наличия транспортных и функциональных связей и общего рекреационного ресурса. Проведено рекреационное зонирование для получения информации о пригодности их территорий для туристско-рекреационного использования.

В статье авторами осущуествлено рекреационное зонирование - где выделено десять рекреационных зон, в которых определень критерии пригодности территории для рекреационно-оздоровительного использования. Доказано, что Закарпатье - живописный уголок, занимает особое место в плане развития рекреационного комплекса Украины, который является уникальный по своим ресурсами и по своему геоэкономическим положением в мире, что делает область привлекательной для оздоровления и отдыха людей и создает приоритетное развитие рекреации в Закарпатье.

Ключевые слова: туризм, рекреационная зона, рекреационные ресурсы, рекреационное зонирование, область, отрасль, информация, анализ, направление, экономика, формирование.

\title{
Recreational areas of Zakarpattia: the state and prospects of development
}

\author{
K. Hirnyak, M. Bagriy \\ girnjak@mail.ru

\begin{abstract}
Lviv National University of veterinary medicine and biotechnology named after S. Gzhytskyj, Pekarska Str.,50,Lviv, 79010, Ukraine,
\end{abstract}

The article discusses the prospects of the state and development of recreational areas of Transcarpathia. Determined that it is in Transcarpathia has great recreational resources, which include geographic features used and can be used for recreation, tourism, medical treatment, rehabilitation population and significantly affect the economic development of the region.

A functional zoning of recreation areas, which is necessary for intra-recreational policy, regional management and regulation of the definition of recreational specialization, which will give impetus to the equalization of socio-economic situation in all administrative districts of the region.

The study of the peculiarities of economic turistichno-rekreaciiynikh resources in the Transcarpathian region of modern recreations using modern social development indicators, including economic competitiveness and globalization. Posted modern and original concepts, including «recreational area»-a set of recreation areas, which are based on territorial proximity, availability of transport and functional relationships and general recreational resource. A recreational zoning for information about the suitability of areas for tourism and recreational use.

In the article the authors made recreational zoning - which highlight ten recreational areas, which defines eligibility for area recreational and recreational use. Proved that Transcarpathia - a picturesque area that has a special place in the plan of recreational complex of Ukraine, which is unique in its resources and in its economic location in the world, which makes the region attractive for recreation and leisure people and creates the priority development of recreation in our region.

Key words: tourism, recreation area, recreational resources, recreational zoning area hazuz, information, analysis, direction, economy formation.

\section{Вступ}

Типологічний підхід є принципово важливим інструментом для суспільно-географічних досліджень областей і регіонів, що дозволяє згрупувати їх за економічними, соціальними, політичними, культурними, екологічними тощо, критеріями і проаналізувати їх місце у конкретних умовах геопростору. Завдяки типологічному підходу ми маємо змогу виявити місце конкретної області у сучасних глобальних і регіональних суспільно-географічних та рекреаційних процесах. Традиційні підходи до економічної типології потребують врахування цих індикаторів, зокрема показників інноваційності економіки, розвитку інфраструктури, рівня глобалізації.

Розвиток рекреаційного комплексу в Україні особливе місце належить Закарпатській області. Закарпаття має великі рекреаційні ресурси, до яких належать географічні об'єкти, що використовуються і можуть бути використані для відпочинку, туризму, лікування, оздоровлення населення, а також суттєво вплинути на розвиток економіки регіону. Саме тому, актуалізується необхідність проведення аналізу функціонування та розвитку кожної рекреаційної зони Закарпаття, а саме: визначення пріоритетних напрямків розвитку туризму та рекреації в даних зонах, виділення основ- них видів туризму в кожній рекреаційній зоні та здійснення їх економічної оцінки.

\section{Матеріал і методи досліджень}

Основні терміни рекреаційного комплексу, туризму, рекреаційних ресурсів, рекреаційного зонування вітчизняні та зарубіжні вчені трактують по-різному. Однак, охарактеризувати всю множину нами визначень термінів у статті неможливо, тому ми обмежилися тими, які на наш погляд, розкривають суть цього питання, зокрема: Блохін Ю.І., Богданов Ю.В., Волков В.С. які розробили принципи розвитку сфери туризму в ринковій економіці; науковці Галенська О.М., Корнєєв С.Є., Тайнович Н.В. розвинули уявлення про механізми регуляції організаційноправових відносин у сфері туризму; дослідники Батюк Б.Б., Карлова Г.А., Казанкіна Т.В., Потьомкін В.К., Яковлева Н.В. сформулювали основи формування ринкової стратегії туристського обслуговування населення; учені Балабанів А.І., Гуденко Н.Б., Шагінов Ю. А., Файбусович Є.Л. запропонували систему заходів для інвестування сфери туризму і формування цінової політики. Проблеми експлуатаційних запасів мінеральних вод Закарпаття досліджував Лобода М.В. Вивчення санаторно-курортних зон, виділення їх у основні групи здійснено у працях Кравціва В.С. та 
Євдокименка В.К. Але практично не досліджено наявні туристично-рекреаціійні ресурси кожної рекреаційної зони та не здійснено економічного аналізу.

Метою дослідження є визначення особливостей економічних туристично-рекреаціійних ресурсів у системі новітніх рекреацій Закарпатської області, що використовують сучасні показники розвитку суспільства, зокрема конкурентоспроможності та економічної глобалізації.

\section{Результати та їх обговорення}

Рекреація є однією з галузей господарства, яка має найбільш динамічні та стабільні показники розвитку. Рекреаційна зона це сукупність рекреаційних регіонів, які формуються на основі територіальної близькості, наявності транспортних і функціональних зв'язків і загального рекреаційного ресурсу (Pokolodna, 2012).

Закарпаття це не просто одна із областей України, а й чудовий край 3 неповторними краєвидами, які перехоплюють подих туристів 3 усіх куточків світу. Відпочинок на Закарпатті всесвітньо відомі мінеральні джерела, садівництво i виноградарство, край мальовничих гір і долин. Своєрідна природа, комфортний клімат, курорти та архітектурні пам'ятки, цікаві літні і зимові маршрути, усе це зробило область краєм масового туризму.

Взимку Закарпаття приваблює своїми чудовими гірськолижними курортами, термальними водами, зимовими базами відпочинку, а в літку своїми зеленими лісами, чистим повітрям, мінеральними джерелами, величчю Карпатських гір, полонин і привітністю закарпатських людей.

Закарпаття має унікальні передумови формування на ринкових засадах рекреаційно-туристичного комплексу, а саме:

- географічна вигідне географічне положення (область є воротами України у Західну Свропу) створює ій певні переваги для прискореної інтеграції в європейські структури, єдина область України, яка межує з чотирма центральноєвропейськими державами; пам'ятний знак «Центр Європи» встановлено поблизу с. Ділове Рахівського району;

- історична своєрідність краю, де збереглась висока культура господарювання, традиції і навики місцевого населення, що у поєднанні з близькістю країн Західної Свропи створює передумови для швидкої адаптації населення до ринкових умов господарювання;

- економічний досягнуті позитивні структурні зрушення служать вагомою передумовою для поступового економічного зростання;

- транспортний розвинута мережа автомобільних доріг та залізниць з врахуванням зручного географічного положення може принести реальну вигоду області;

- природний наявність унікальних природних ресурсів: мінеральних вод, лісів, значних запасів підземних і поверхневих вод, інших корисних копалин індустріального значення, ландшафтно-кліматичних зон (на Закарпатті знаходиться найбільша вершина
Українських Карпат гора Говерла (2061); бере свій початок одна 3 найбільших річок Свропи Тиса; єдина в Україні Долина нарцисів поблизу м. Хуст; високогірне озеро Синевір, розташоване на висоті 989 м);

- рекреаційний область володіє потужним природним потенціалом для санаторно-курортного лікування та оздоровлення людей, який може перетворити рекреаційну сферу в одну з провідних галузей економіки області (с. Солотвино Тячівського району знаходиться найбільша у світі алергологічна лікарня, розміщена у солоній шахті на глибині 300 м);

- екологічний порівняно низький рівень антропогенного забруднення довкілля та виняткова екологічна роль Карпат на континенті сприяють позитивному іміджу області.

Закарпатська область має високий природнорекреаційний i туристично-курортний потенціал. Щедра природа дарує хворим одужання, а здоровим насолоду. У багатьох містах і селах на водах було споруджено водолікарні, купальні або бальнеологічні санаторії. Мінеральні води допомагають при захворюваннях опорно-рухового апарату, дерматологічних та гінекологічних хворобах, при патологіях органів травлення та нервової системи. Під Закарпаттям ціле море цілющих вод. Де б не робили свердловину, майже напевно натрапляли на мінеральне або геотермальне джерело.

Серед гідромінеральних та природнорекреаційних ресурсів вивчено 360 джерел мінеральних вод, різноманітних за своїм складом та лікувальними можливостями. Деякі родовища унікальні, їх води відповідають типу «Єсентуки», «Боржомі» та «Нарзан» і не поступаються відомим водам Чехії, Польщі, Франції. В області нараховується понад 20 родовищ субтермальних і термальних, високо термальних вод. Наявність мікроелементів у складі мінеральних вод Закарпаття дає повне право віднести цілий ряд родовищ до унікальних, а їх води до високоефективних і цінних при використанні для лікування та профілактики захворювань різних органів людини. На базі цих унікальних джерел в області функціонує цілорічно багато санаторіїв: «Поляна», «Сонячне Закарпаття», «Квітка Полонини», «Верховина», «Шаян» для лікування захворювання органів травлення; «Карпати», «Перлина Карпат», «Теплиця» для лікування серцево-судинної та нервової системи; «Синяк», «Гірська Тиса» для лікування захворювань опорно-рухових органів (Musatkina, 2006).

Функціональне зонування рекреаційних територій $\epsilon$ основою рекреаційного зонування як важливої передумови здійснення політики розвитку сфери санаторно-курортного лікування, туризму і відпочинку в регіоні.

Рекреаційне зонування необхідне для проведення внутрішньорегіональної рекреаційної політики, регіонального управління та регулювання визначення рекреаційної спеціалізації, яка дасть імпульс до вирівнювання соціально-економічної ситуації в усіх адміністративних районах області. Перш за все потрібно визначити територіальну організацію рекреаційнооздоровчого комплексу та охарактеризувати іï форми. 
Найпростішою формою сучасної територіальної організації рекреаційно-оздоровчого комплексу $\epsilon$ рекреаційний пункт, який являє собою окремо розміщені спеціалізовані заклади. Досконалішою формою $\epsilon$ рекреаційні центри та вузли. Рекреаційні центри це окремі населені пункти 3 набором рекреаційних закладів або окремих об'єктів, що виступають центрами формування рекреаційного вузла, а рекреаційні вузли це сукупність рекреаційних центрів на компактній території. Сукупність рекреаційних пунктів, центрів, вузлів, що спільно використовують рекреаційні ресурси і розташовані на ній інфраструктурні райони, найчастіше поліфункціональні, а саме курортнооздоровчі. Як найвищі таксономічні одиниці територіально-рекреаційного-обслуговування можуть виділятися рекреаційні регіони та зони. Рекреаційний регіон це група рекреаційних районів у межах певних територій, що характеризуються спільністю природних та історико-культурних ресурсів, єдиними інфраструктурними взаємозв'язками (Shkola, 2005).

Функціональне зонування рекреаційних територій здійснюється на основі оцінки придатності території для різних видів рекреаційної діяльності. В. Кравців та В. Свдокименко відповідно до видів рекреаційної діяльності окреслюють наступні види рекреаційних зон лікувально-оздоровчого профілю у Закарпатській області (Kravciv et al., 1995; Yevdoky`menko, 1996):

- зони санаторно-курортного лікування Свалявська, Шаянська та Поляно-Квасівська;

- оздоровчі зони Рахівсько-Ясінянська та Великоберезнянська. При цьому вони виділяють такі рекреаційні райони Берегівський, РахівськоЯсінянський, Воловецько-Міжгірський, СвалявськоМукачівський та Великоберезнянський.

Берегівський район за В.Кравцівом та В.Свдокименком охоплює територію у межах двох адміністративно-територіальних одиниць Берегівського та Виноградівського районів, тому, на нашу думку, цей район слід було назвати БерегівськоВиноградівським. Територія цього району придатна для організації оздоровлення, туризму (Берегово, Виноградів), а також санаторно-курортного лікування (родовища мінеральної води в с. Велика Бігань), але рекреаційні ресурси майже не використовуються.

Рахівсько-Ясінянський район представлений лікувальними мінеральними водами (Кваси, Кобилецька Поляна, Косівська Поляна та ін.), унікальними ландшафтами, пам'ятками історії та культури. Основна галузь рекреаційної діяльності зимові види спорту та відпочинку (Ясіня, Рахів), санаторно-курортне лікування (Кваси, Кобилецька Поляна, Косівська Поляна). Район непогано освоєний у рекреаційному відношенні, проте є можливості для подальшого розширення рекреаційного господарства.

На території Воловецько-Міжгірського рекреаційного району є унікальні мінеральні води (Сойми, Келечин, Синевірська Поляна), середньогірські ландшафти, старі ліси, цілющий клімат. Основні види рекреаційної діяльності санаторно-курортне лікування, зимові види спорту та відпочинку, пізнавальний туризм. Найбільші рекреаційні центри Сойми, Келечин, Пилипець, Синевірська Поляна, Міжгір'я, Воловець.
Свалявсько-Мукачівський рекреаційний район характеризується наступними видами рекреаційних ресурсів лікувальні мінеральні води, пам'ятки історії та культури. Район спеціалізується на санаторнокурортному лікуванні та оздоровленні. Тут функціонує 5 курортів (Карпати, Квітка Полонини, Плоске, Поляна та Синяк) і $є$ значні можливості для рекреаційної діяльності.

Великоберезнянський рекреаційний район володіє лікувальними мінеральними водами та мальовничими ландшафтами. Тут створений міжнародний біосферний заповідник «Стужиця» (Yevdoky`menko, 1996).

Офіційна статистика Закарпатської області виділяє 10 рекреаційних зон на iї території: Ужгородська рекреаційна зона та курорт Деренівка, Мукачівська та курорти Карпати i Синяк, ВеликоберезнянськоПеречинська, Міжгірсько-Воловецька та курорт Сойми, Свалявська та курорт Поляна, Іршавська, Берегівська, Хустсько-Виноградівська та курорт Шаян, Тячівська, Рахівська та курорт Кваси. Найбільше насичені санаторно-оздоровчими закладами Свалявська та Мукачівська зони.

Ужгородська лікувально-оздоровча зона базується на лікувальних властивостях слабомінералізованих кремнистих мінеральних вод Ужгородського та Деренівського родовищ, високомінералізованої гідрокарбонатної натрієвої води родовища Руські Комарівці. На території рекреаційної зони розміщені курорт «Деренівка» 3 санаторним комплексом «Деренівська купіль» та санаторій «Малятко».

Мукачівська лікувально-оздоровча зона володіє родовищами сульфідних вод та термальних вод декількох типів. На території зони розташовані кліматобальнеологічний курорт «Карпати» (санаторії «Карпати» та «Перлина Карпат») та бальнеологічний «Синяк» (санаторії «Синяк» та «Солені млаки»).

Великоберезнянсько-Перечинська лікувальнооздоровча зона базується на родовищах мінеральної води різних типів. На іiі території знаходиться оздоровчо-лікувальний комплекс «Дубриничі» та багато інших баз відпочинку.

Міжгірсько-Воловецька лікувально-оздоровча зона характеризується унікальними вуглекислими мінеральними водами кількох типів з найбільшими запасами для Закарпаття. Тут розташований бальнеологічний курорт Сойми із санаторієм «Верховина».

За класифікацією статистичного управління області Свалявська лікувально-оздоровча зона представлена бальнеологічним курортом «Поляна», що базується на лікувальних вуглекислих гідрокарбонатних натрієвих водах різної мінералізації. На його території розташовані санаторії «Поляна», «Квітка Полонини», «Сонячне Закарпаття», «Кришталеве джерело» та «Човен».

Виділення окремої Іршавської лікувальнооздоровчої зони обумовлюється наявністю найбільших родовищ термальних метанових хлоридногідрокарбонатно-натрієвих та йодо-бромних вод, що практично не використовуються.

Берегівська лікувально-оздоровча зона базується на значних запасах термальних вод трьох типів кремнисті, азотні та азотно-метанові йодо-бромні хлорид- 
ні натрієві. На використанні їх лікувальних властивостей функціонував санаторій-профілакторій «Косино».

На території Хустсько-Виноградівської лікувально-оздоровчої зони розміщені курорт Шаян із санаторіями «Шаян» і «Байлово» та санаторій «Теплиця», які використовують родовища вуглекислих мінеральних вод.

Тячівська лікувально-оздоровча зона характеризується наявністю різних типів мінеральних вод, ропи та палагових грязей солених озер. На території зони розташовані Українська та обласна алергологічні лікарні та санаторій «Мінерал».

Рахівська лікувально-оздоровча зона базується на родовищах мінеральних вод різних типів. На його території розташований бальнеологічний курорт Кваси із санаторієм «Гірська Тиса», що використовує вуглекислі миш'якові води.

Основними критеріями, що визначають придатність території для рекреаційно-оздоровчого використання $є$ наявність родовищ мінеральних вод та інших бальнеологічних ресурсів, а також сприятливих кліматичних та екологічних умов.

На територіях розміщення природних лікувальнооздоровчих та рекреаційних ресурсів «полюсами зростання» локального і регіонального значення виступають курортно-рекреаційні підприємства, діяльності яких властивий мультиплікаційний ефект зростання попиту на їх послуги викликає підвищений попит на курортне будівництво, продукцію суміжних галузей, послуги транспорту, сервісних центрів, комунікацій, індустрії розваг, харчування тощо. Усе це супроводжується інвестиційним піднесенням, розширенням зайнятості, зростанням податкових надходжень до бюджетів, тобто економічного пожвавлення, яке за умов нерозвиненості курортних технологій має сезонну динаміку (Batyuk, 2015).

\section{Висновки}

Закарпаття мальовничий куточок, що займає особливе місце у плані розвитку рекреаційного комплексу України, який є унікальний за своїми ресурсами i за своїм геоекономічним положенням у світі, що ро- бить область привабливою для оздоровлення та відпочинку людей і створює пріоритетний розвиток рекреації у Закарпатті. Для успішного визначення напрямків та видів туризму, проведення внутрішньорегіональної політики, щодо проведення рекреаційного зонування, де виділено десять рекреаційних зон, в яких визначено критерії придатності території для рекреаційно-оздоровчого використання. Закарпаття володіє всім необхідним для розвитку сучасної туристичної індустрії. Оскільки жодна галузь світового господарства не працює так інтенсивно й стабільно як туризм.

\section{Бібліографічні посилання}

Pokolodna, M.M. (2012). Rekreacijna geografiya: navch. posib. dlya stud. vy`shh. navch. Zakl. Xark. nacz. akad. mis`k. gosp-va. X.: XNAMG (in Ukrainian).

Musatkina, V.P. (2006). Diagnosty'ka stanu ta perspekty`vy` rozvy`tku tury`sty`chno-rekreacijnogo kompleksu Zakarpattya. Naukovy`j visny`k NLTU Ukrayiny`: zbirny'k naukovo-texnichny`x pracz'. L`viv: NLTU Ukrayiny`. 16(1), 456 (in Ukrainian).

Shkola, I.M. (2005). Menedzhment tury`sty`chnoyi industriyi: Navch. pos. Chernivci: Kny`gy` XXI (in Ukrainian).

Yevdoky`menko, V.K. (1996). Regional’na polity`ka rozvy`tku tury`zmu: Metodologiya formuvannya, mexanizm rekreaciyi. NAN Ukrayiny`. Insty tut regional'ny`x doslidzhen`. Chernivci: Prut (in Ukrainian).

Kravciv, V.S., Yevdoky'menko, V.K., Gabrel', M.M., Kopach, M.V. (1995). Rekreacijna polity`ka V Karpats 'komu regioni: pry`ncy`py` formuvannya, shlyaxy` realizaciyi. Chernivci: Prut (in Ukrainian).

Gudz', P.V. (2003). Mexanizm rozvy`tku kurortnorekreacijny'x tery`torij $\mathrm{v}$ suchasny'x umovax: avtoref. dy`s. na zdobuttya nauk, stupenya doktora ekon.nauk / Insty`tut ekonomiko-pravovy'x doslidzhen` NAN Ukrayiny`. Donecz`k (in Ukrainian).

Batyuk, B.B. (2015). Novitni rekreacijni zony' svitu. Regional na ekonomika. L'viv. 3(7), 45-52 (in Ukrainian)

Стаття надійшла до редакичї 1.09.2016 